\title{
Assessment of rock slope stability and structurally controlled failures along Samma escarpment road, Asir Region (Saudi Arabia)
}

\begin{abstract}
Samma escarpment road is located in Asir Region, Saudi Arabia. It is located NW of Abha city. This escarpment road represents a major corridor in the area which connects different cities and touristic resorts in the region. It is descended from Sudah plateau at about $2700 \mathrm{~m}$ above sea level (asl) toward Wadi al Aws at about $1500 \mathrm{~m}$ asl. The total length of the road section is about $8 \mathrm{~km}$ which is passing through a highly mountainous area characterized by a complex geological and structural elements. This road has been exposed to frequent slope failures from time to time due to various factors such as intense rain storms, different geological and structural elements (weak rocks, shear zones, and faults), road characteristics (different horizontal/vertical curvatures and narrow road section), and human activities (uncontrolled rock cuts). Many sliding events have been documented along this escarpment road, particularly during and following rainstorms. The purpose of this paper is to evaluate the geology and structures by applying the rock mass rating (RMR) and slope stability (structurally controlled failures) along the Samma escarpment road. The stability analysis was performed using two Dips and RockPack III programs with the help of RocLab software. The Summa escarpment rock cuts were classified into 51 stations which were investigated in detail. Results indicated that most rock stations are poor quality, and 31, 32, and 41 stations are stable, 4, 6, and 7 stations are marginally stable, and 16, 13, and 3 stations are potentially unstable due to planar, wedge, and toppling failures, respectively. Finally, different recommendations and remediation methods were suggested as mitigation measures.
\end{abstract}

Keyword: $\quad$ Landslides; Slope stability; GIS; Structure; Saudi Arabia 